\title{
Article
}

\section{Identification of Factors for the Development of Medical Tourism in the World}

\author{
Viktoriia Vovk $^{1, *(\mathbb{D}}$, Lyudmila Beztelesna ${ }^{2}$ and Olha Pliashko $^{3}$ \\ 1 Department of Economics, Stanisław Staszic University of Applied Sciences in Piła, 64-920 Piła, Poland \\ 2 Department of Management, Academic and Research Institute of Economics and Management, \\ National University of Water and Environmental Engineering, 33028 Rivne, Ukraine; \\ 1.i.beztelesna@nuwm.edu.ua \\ 3 Department of Economics and Business Management, Faculty of Documentary Communications, \\ Management, Technology and Physics, Rivne State University of Humanities, 33000 Rivne, Ukraine; \\ olga.plyashko@rshu.edu.ua \\ * Correspondence: viktoria.vovk@puss.pila.pl
}

Citation: Vovk, V.; Beztelesna, L.; Pliashko, O. Identification of Factors for the Development of Medical Tourism in the World. Int. J. Environ. Res. Public Health 2021, 18, 11205. https://doi.org/10.3390/ijerph 182111205

Academic Editor: Ceri J. Phillips

Received: 28 July 2021

Accepted: 12 October 2021

Published: 25 October 202

Publisher's Note: MDPI stays neutral with regard to jurisdictional claims in published maps and institutional affiliations.

Copyright: (c) 2021 by the authors. Licensee MDPI, Basel, Switzerland. This article is an open access article distributed under the terms and conditions of the Creative Commons Attribution (CC BY) license (https:// creativecommons.org/licenses/by/ $4.0 /)$.

\begin{abstract}
The overall objective of the given paper was to study the relationship of inbound medical tourism destinations with international tourism, economic development of recipient countries, the development of national healthcare systems and the institutional features of their environment, in terms of protection of the rights and freedoms of both business and citizens. In order to achieve this objective, the authors used methods of grouping, as well as correlation and regression analysis. The conducted study revealed that the formation of medical tourism destinations in countries with high social and economic development occurs in a balanced and unidirectional manner; simultaneously, one can see that the countries with "new economic development" form a sufficiently powerful and competitive market for medical tourism. All these countries have one thing in common: namely, there is a link between medical tourism and healthcare funding, international tourism and development of political and civil freedoms. Nevertheless, the noted aspects are not dominant enough, and this indicates that there are other internal factors and their configurations which shape a positive image of countries for medical tourism development. This finding leads to the necessity of further analysis in this field with a breakdown into separate countries or destinations.
\end{abstract}

Keywords: medical tourism; international tourism; economic growth; healthcare service; healthcare system; institutional environment

\section{Introduction}

The history of medical tourism is very ancient. Most ancient civilizations recognized the therapeutic effect of mineral thermal springs and sacred baths, which provoked travel [1]. Nonetheless, with each passing year, more and more people are interested in overseas medical and health services. Longing to improve their health, people increasingly travel abroad in the hunt for medical care and spend a significant share of their savings. On the other hand, the comprehensive satisfaction of the needs of the medical tourist during his/her visit to the destination country allows countries to receive significant budget revenues, while developing new markets for tourism services.

Medical tourism, like any other type of tourism, is undoubtedly an important component of a steady-state economy. It can contribute to economic diversification and increase of the country's profitability not only through the inflow of foreign currency, but also by increasing employment of local people, improving the skills of local staff, stimulating investment in healthcare, improving the quality of medical and associated services, as well as improving the health of the country's own nation. According to Simpson L., people can travel from developed to developing countries and vice versa. In the first case, tourists search for cheaper medical services when there are viable technologies. In the second case, 
they search for services that are unavailable or are of an unsatisfactory quality in their country [1]. It is no wonder that the competition for attracting tourists in the global market is constantly growing.

In recent decades, medical tourism, as a branch of the tourism economy [2], has been growing quite actively. Patients, especially from developed countries, are increasingly seeking medical care across national borders. People's desire to be constantly aware of their health, as well as to be in the trend of a healthy lifestyle, encourages not only timely treatment, but also regular health procedures and preventive medical examinations. Therapeutic, rehabilitative and preventive procedures provided by sanatoriums, prevention and treatment facilities and polyclinics facilitate the recovery of patients with chronic cardiovascular, orthopedic, rheumatologic and neurological diseases. Besides, the above procedures attract young people who pay great attention to a healthy lifestyle and physical fitness [3]. Such aspirations, combined with the ease of travel between countries, have led to the growth of medical tourism as a growing industry in many countries [4]. The rise of medical tourism emphasizes the privatization of health care, the growing dependence on technology, uneven access to health resources and the accelerated globalization of both health care and tourism [5].

According to the World Tourism Organization, there has recently been a steady trend of tourism growth in all directions. Throughout 2009-2018, the number of trips related to visiting friends and relatives, medical treatment and improving health, as well as visits for religious reasons increased from 252.32 million people to 377.67 million people [6].

International tourism in the context of travel has always included an economic basis, which was merely consigned to travelers' purchases of various goods and services [7-9], including medical ones. In the latter case, the purpose of such purchases for the person consuming the service was to attain health or subjective well-being [10].

Medical tourism, as such, has existed since ancient times [11]; however thanks to the processes of globalization, it has become widespread. The reasons for this growth are the following: the cost of treatment in wealthy countries, the long queues for certain types of medical services (especially in cases of surgery), the availability of better technologies, practitioners and paramedical staff abroad, the greater variety of medical institutions and methods and treatments, inadequate or completely absent health insurance, the need to maintain anonymity in treatment, the unavailability (prohibition) of necessary treatment at home (e.g., for ethical reasons), the comparable availability of air fares in combination with the availability of direct connections and contributory exchange rates between the countries, etc. [5,11-15].

The emergence of tour operators, intermediaries between international patients and healthcare networks, which offer various packages of medical services for different types of budgets, also contributes to a significant intensification of medical tourism development. Their main mission is to provide information on the destination, with a detailed description of the quality of healthcare and the surrounding infrastructure [16].

The process of planning a trip is due, in no small part, to associated services, which arise mainly due to the accompaniment of tourists by members of their families. Therefore, together with medical tourism growth, other sectors of the economy actively develop at the same time, which leads to the fact that the state treasury shall be filled with foreign currency $[17,18]$.

- The interests of a medical tourist largely coincide with the interests of an international tourist; however, despite the common features, medical tourism has its own features: within the framework of medical tourism, the pleasure of traveling arises not only during the trip itself, but also after the return of the tourist to his/her home, when the patient can feel the long-term improvement of his/her health;

- Traveling in pairs is often a necessity, which can be caused by the desire to feel safer during treatment and to receive additional supervision and assistance in unforeseen situations; 
- Usually, medical tourists are characterized by higher incomes and qualifications than ordinary international tourists, and, as a rule, such trips are initiated by women [19], who, unlike men, are more prone to such trips.

These differences arise primarily due to other motivations of medical tourists. The key motives of medical tourism include the following:

1. Commercial factors (lower cost of treatment and diagnosis in developing countries; combination of medical tourism with traditional tourism, which is the priority patient);

2. Qualitative factors (more modern level of medical technologies, expectations of more qualified medical care and service, focus on the medical achievements of the selected doctor) [20];

3. Social factors (lack of paid health insurance in their country, presence of health insurance that does not cover the disease, lack of full state health insurance combined with high cost of private health insurance, unavailable procedures, i.e., "bypass tourism", or procedures that are not provided in their country) [11,15,21,22];

4. Personal factors (the need to maintain confidentiality, the bias of the patient's views, previous personal experience or the experience of people in the circle of trust, i.e., intimate circle).

It is clear that the study of medical tourism should be comprehensive, as it is integrated into the economic, social, cultural, personnel and local structure. In the economic literature, there are numerous studies on the interaction of medical tourism with economic growth [23-27]. They revealed that this type of tourism can contribute to economic diversification and profitability by increasing employment, ensuring the provision of healthcare facilities with material resources and improving capital turnover. There are also additional bonuses; as such, a country can count on increasing demand for medical services in the domestic market, as well as improving public health, while this process, in the long run, will once again have a positive impact on economic development [28].

Having studied the specific functioning of modern medical systems concerning the dynamics of healthcare spending in BRICS countries (Brazil, Russia, India, China, and South Africa), scientists from the United States, India, Russia, and Serbia highlighted the economic benefits of healthcare. Besides, they pointed out that the bold gains in the living standard and purchasing power of citizens gives momentum for all of the BRICS to increase investment in health care, far more than majority of nations worldwide [29]. Three clear patterns were also established as follows: (1) the significant increase in the share of Brazil, Russia, India, China and South Africa in global health expenditures from 1995 to 2013; (2) the strong dominance of Chinese national spending among the BRICS countries studied; (3) the long-term trend of increasing the share of global health spending of the BRICS compared to the leading industrialized G7 countries.

The effectiveness of health systems was the subject of a cross-regional comparison of health reform outcomes in Southeastern Europe between 1989 and 2012. Using macroeconomic indicators, researchers found significant differences in health resources and system outcomes of three policy legacies (post-Semashko Eastern European countries, the former Yugoslavia and free-market countries before 1989). Through the evaluation of selected indicators of health system capacity and resource availability, it was illustrated that, despite the different historical legacies of each group of countries under study, they were able to increase life expectancy, ensure better survival of newborns and reduce the number of hospitalized patients. At the same time, these different paths to common goals created a golden opportunity for these economies to learn from each other [30]. While recognizing the importance of medical tourism for the entire economy, the overall objective of the given research was to identify the impact of economic development factors of states, their institutional environment and the performance of national healthcare systems on the formation and development of progressive tendencies for medical tourism. Pursuing this objective gives an opportunity to identify which factors are decisive for the development of medical tourism in recipient countries. This part, in turn, will shape strategic priorities for the development of national healthcare systems based on the partnership between businesses 
and the state, allowing a country to actively compete in the medical tourism market, while forming a positive image of oneself in the international arena and increasing one's own well-being. Hence, the hypothesis of our study was that the formation and development of inbound medical tourism destinations is associated with international tourism and economic development of recipient countries, the development of national healthcare systems and the institutional features of their environment, in terms of protection of the rights and freedoms of both business and citizens.

The given paper is structured as follows. Based on the literature review, the main section presents the specifics of the functioning of medical tourism and the views of scientists on the factors of intensification of medical tourism development, which allowed the authors to form a research hypothesis. The next section describes the methodological aspects of the research and provides the sources of the research materials. The final section closes with the results of the research and conclusions.

\section{Materials and Methods}

In order to test the hypothesis, the given study chose the rating value of the countries, according to the Medical Tourism Index (MTI), developed by the International Health Research Center, as an evaluation indicator of medical tourism development. The importance of studying the impact of this indicator is determined by the fact that this indicator specifically gauges any consumer interest and may be used in future MTIs to focus on some of the most sought-after target markets [31].

Particularly for the research purposes, the countries for which information is given in the MTI were selected. It was found that it is reasonable to choose the Medical Tourism Index for 2016, as not all of the studied indicators had data available for a later date. Some of the countries included in the MTI ranking (United Arab Emirates, Taiwan and Korea) were not included in our study. The reason for this is that on other indicators, the data regarding these countries are summarized (for instance, there are aggregated indicators for the United Arab Emirates, without division into the emirates of Dubai and Abu Dhabi) or absent (in case of Korea and Taiwan), which makes conducting qualitative research and comparison impossible. Thus, the study included 37 countries out of the 41 included in the 2016 MTI rankings.

The economic development of countries was assessed with the use of the GDP per capita. The evaluation of international tourism was carried out according to the indicators of the Travel and Tourism Competitiveness Index (TTCI), the number of international tourist arrivals, revenues from international tourism and the increase in tourism investments in 2016 compared to 2015 (Appendix A Table A1).

The development of national health care systems was assessed with the use of current expenditure on health per capita in US dollars (total and state), domestic general government expenditure on health per capita in US dollars, the share of private and out-ofpocket health expenditures and the number of hospital beds and doctors/physicians per 1000 people (Table A2).

Aiming to assess the institutional environment of countries that are medical tourism destinations, we analyzed international competitiveness indices (their absolute values) of the noted states, namely the Global Competitiveness Index (GCI), Human Development Index (HDI), Corruption Perceptions Index (CPI), Doing Business (DB) index, the International Property Right Index (IPRI), the Index of Economic Freedom (IEF), Political Rights Index (PRI) and Civil Liberties Index (CLI) (Table A3).

The research used the subsequent information databases, and this allowed collecting, summarizing and processing the following indicators:

1. The report on Medical Tourism Index-Global Destination [32] for Medical Tourism Indices;

2. The Travel \& Tourism Competitiveness Reports [33] for the indicators of the Travel and Tourism Competitiveness Index; 
3. The World Data Atlas [34] for the indicators on international tourism, arrivals and incomes from international tourism, investment growth, GDP per capita, current expenditure on health per capita, domestic general government expenditure on health per capita, private health expenditures per capita, out-of-pocket expenditure, doctors per 1000 people and hospital beds per 1000 population;

4. Official reports on international indices for indicators such as the Global Competitiveness Index [35], Human Development Index [36], Corruption Perceptions Index [37], as well as for indicators such as Doing Business, the International Property Right Index, the Index of Economic Freedom, Political Rights Index and Civil Liberties Index [34].

In order to determine the foremost mega-destinations for medical tourism, we used the method of grouping by geographical feature. Aiming to assess the economic development of countries, national healthcare systems and the institutional environment, we developed a matrix of grouping countries by appropriate indicators (with the presentation of above and below average), based on their absolute value compared to the arithmetic mean of the whole. We used the Microsoft Excel software toolkit to create a scatter plot for countries, according to the studied indicators. Conversely, for establishing cause-andeffect links between MTI and international tourism indicators, we used a correlation and regression analysis.

\section{Results and Discussion}

The Medical Tourism Association has developed the conceptual model of the Medical Tourism Index (MTI), and it takes into account environmental factors (economy, security, image, culture), the medical tourism industry (destination attractiveness and medical tourism costs) and the quality of care (quality of healthcare services, reputation of physicians/doctors and healthcare institutions, international accreditations and satisfaction of patients with the quality of medical care and service). According to this study, the foremost medical tourism mega-destinations are as follows (Figure 1): (1) the American region (Canada, Colombia, Costa Rica, Panama, Jamaica, Brazil, Argentina, Mexico, etc.), with its dominant areas of dentistry and cosmetic surgery mainly for U.S. residents; (2) the European region, with countries specializing mainly in the treatment of cancer, cardiology and orthopedic diseases (Great Britain, France, Germany, Italy, Spain, Poland, Russia); (3) the Arab and Middle Eastern region (Bahrain, Egypt, Iran, Israel, Jordan, Kuwait, Lebanon, Morocco, Tunisia, Turkey, Said Arabia, Turkey, Qatar, etc.), with countries specializing in the treatment of oncological diseases, reproductive medicine, cosmetic and plastic surgery and eye microsurgery; (4) African (South Africa and Republic), with countries specializing in the treatment of oncological diseases, reproductive medicine, cosmetic and plastic surgery and eye microsurgery and Asian regions (China, India, Japan, Singapore, Thailand, Korea), with its well-developed practices of general medical examinations and alternative medicine, radical and cosmetic surgery (including sex reassignment) and cancer treatment.

Top medical tourism countries by total rating worldwide included Canada (overall MTI score: 76.62), Great Britain (overall MTI score: 74.87), Israel (overall MTI score: 73.91), Singapore (overall MTI score: 73.56) and India (overall MTI score: 72.1). The countries that had the lowest positions in the MTI rankings included Iran (overall MTI score: 36), Lebanon (overall MTI score: 49.92), Bahrain (overall MTI score: 51.99), Saudi Arabia (overall MTI score: 52.43) and Kuwait (overall MTI score: 52.69). At the same time, for most countries, there was no stable relationship between the country's MTI ranking and the level of their economic development in terms of GDP (Figure 2). 


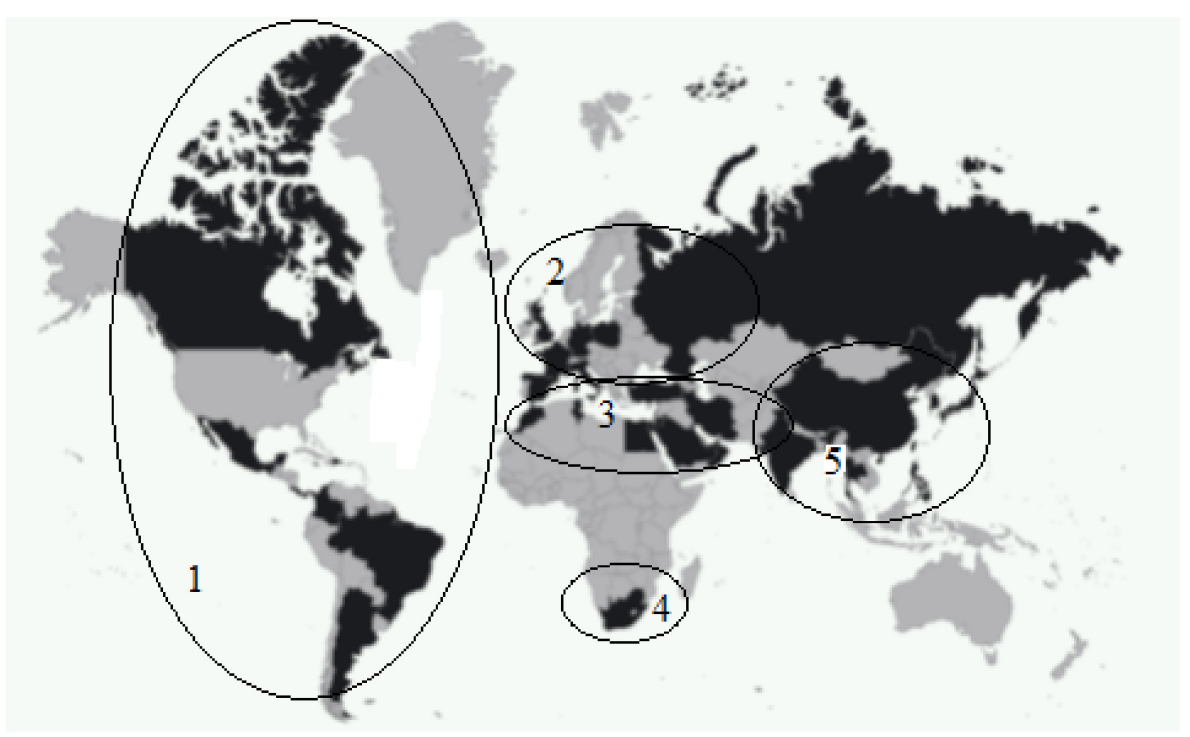

Figure 1. Mega-destinations for Medical Tourism According to MTI, 2016. Legend: 1-American region, 2-European region, 3-Arab and Middle Eastern region, 4-African region, 5-Asian region.

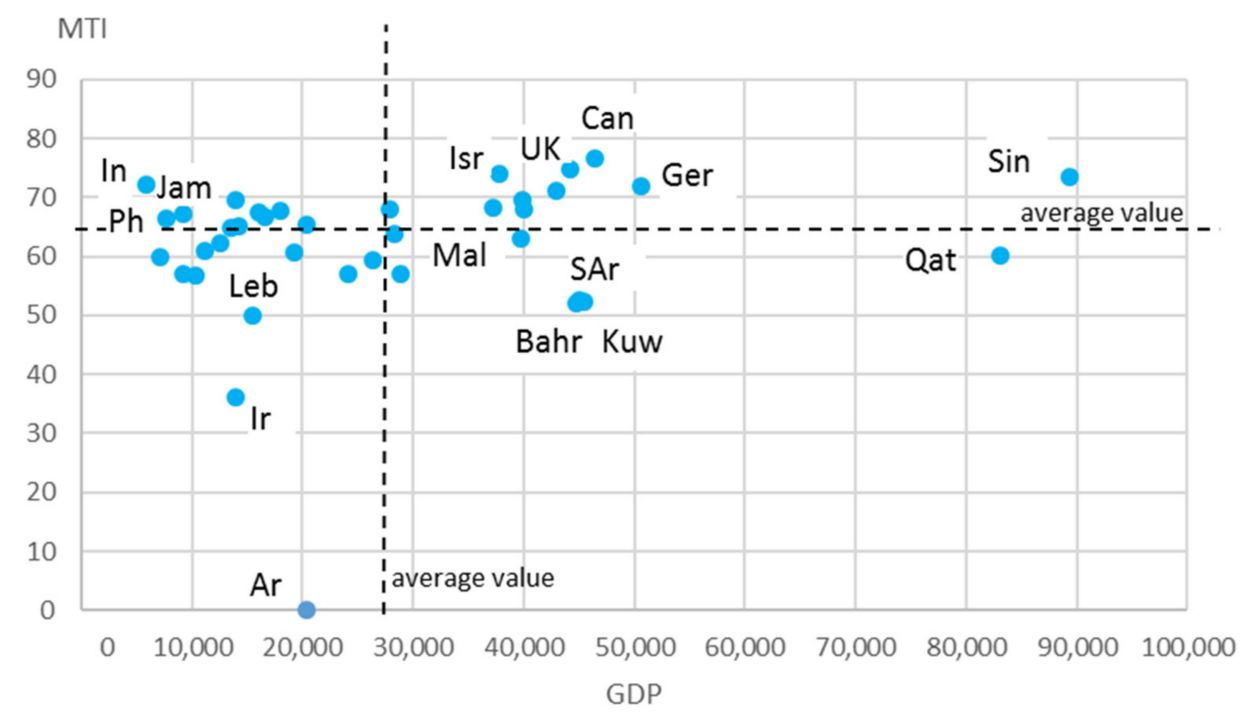

Figure 2. Scattering of Countries According to MTI and GDP per capita. Symbols of countries: Ar-Argentina, Bahr-Bahrain, Can-Canada, Ger-Germany, In-India, Ir-Iran, Isr-Israel, JamJamaica, Kuw_Kuwait, Leb_Lebanon, Mal-Malta, Ph—Philippines, Qat-Qatar, SAr-Saudi Arabia, Sin-Singapore, UK-United Kingdom.

The countries with a relatively high level of GDP per capita did not necessarily occupy leading positions in the MTI ranking (e.g., Bahrain, Saudi Arabia, Qatar and Kuwait). At the same time, low GDP was not associated with a low MTI ranking (e.g., India, Philippines and Jamaica). There was also no correlation between these indicators (the correlation coefficient was 0.214123).

While tracing the links between the MTI rankings and the Travel and Tourism Competitiveness Index, TTCI, one can see that they are somewhat different (Figure 3). Most countries with a high TTCI rating (above average) had top ranking positions for the MTI (4th quadrant: Spain, Canada, Singapore, Great Britain, Germany, France, etc.). Similarly, most countries with a low TTCI level had low positions (below average) according to the MTI (1st quadrant: Bahrain, Kuwait, Iran, Lebanon, Kuwait, etc.). These are mainly countries in the Arab and Middle Eastern regions, with relatively high GDP levels. 


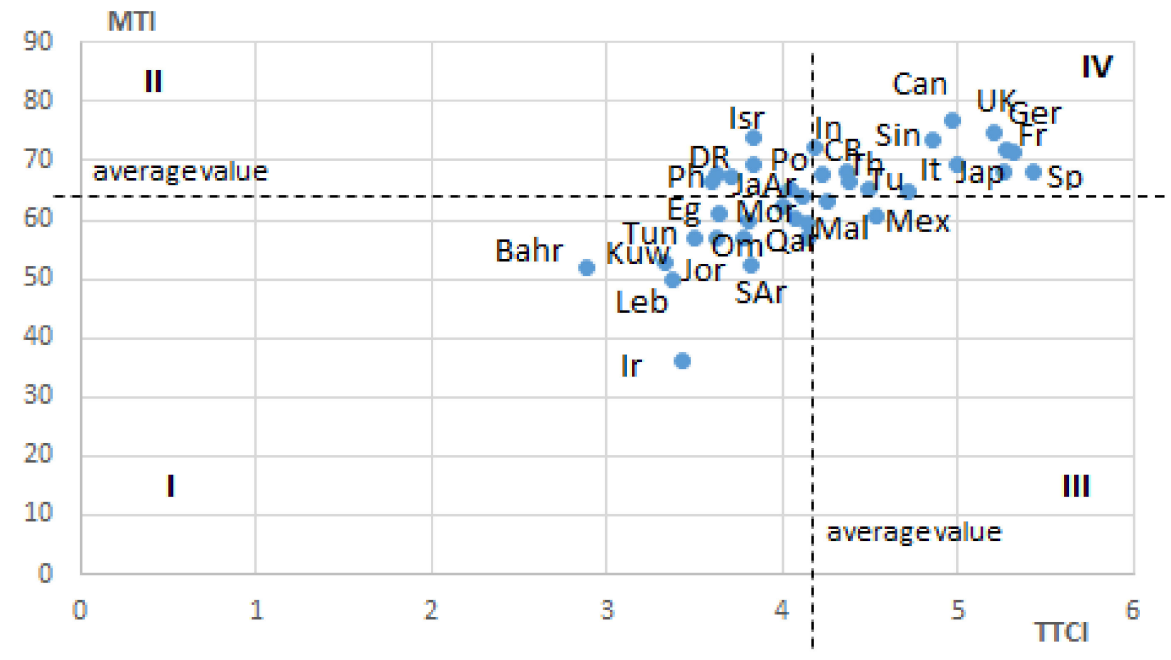

Figure 3. Scattering of Countries According to MTI and TTCI Indicators. Symbols of countries: ArArgentina, Bahr-Bahrain, Ca-Canada, CR-Costa Rica, DR-Dominican Repub-lic, Eg-Egypt, Fr-France, Ger-Germany, In—India, Ir-Iran, Isr-Israel, It—Italy, Ja -Jamaica, Jap-Japan, JorJordan, Kuw-Kuwait, Leb-Lebanon, Mal-Malta, Mex-Mexico, Mor-Morocco, Om-Oman, Ph-Philippines, Po-Poland, Qat-Qatar, SAr—Saudi Arabia, Sin-Singapore, Sp -Spain, ThThailand, Tun-Tunisia, Tu-Turkey, UK-United Kingdom.

In the context of the studied relationship, there were specific features in the cases of the countries with a low TTCI ranking (below average) and high MTI (2nd quadrant: countries of the American region, like Dominican Republic, Jamaica, Philippines, Argentina, etc. and Israel), as well as a high TTCI and low MTI (3rd quadrant: Mexico and Malta). There was a correlation between the MTI and TTCI indicators; however, its parameters (correlation coefficient was equal to $0.66201, R^{2}=0.4383, p<0.05$ ) did not indicate its cause-and-effect (causal) nature.

Given the absolute characteristics of international tourism, we could identify the following groups of countries: countries with a high level of both medical and international tourism development (India, Spain, Japan, Jamaica, Philippines, Panama and Singapore) and countries with a high medical tourism ranking and below average international tourism indicators (Canada, Great Britain, Germany, Israel, Colombia, Thailand, Argentina, Brazil, China and Israel). These groupings allowed us to make assumptions about the target orientation of medical tourists to these countries, as well as to Arab countries (Kuwait, Saudi Arabia, Iran and Oman), where the international tourism indicators were higher, while medical tourism indicators were below average, which most likely indicates the formation of relatively new destinations for medical tourism (Table 1).

The presence of correlations (Table 2) between the indicators studied above, as well, indicates the existence of a link between medical and international tourism. Nevertheless, the further regression analysis (Table A1) for acceptable parameters of the model showed a statistically significant relationship with only one indicator: international tourism revenue (here, we considered incoming international tourism arrivals). The coefficient of elasticity for this indicator $(\mathrm{E}=0.107)$ indicated the insignificant role of incoming cash flows from international tourism in the formation of the MTI ranking, as an increase in revenues from international tourism by $1 \%$, in a certain set of countries, may increase the ranking MTI value by $0.11 \%$. However, such dependencies may be different in cases of different countries. 
Table 1. Matrix of Grouping Countries by Medical and International Tourism Indicators.

\begin{tabular}{|c|c|c|c|c|}
\hline $\begin{array}{l}\text { The Value of } \\
\text { Indicators }\end{array}$ & $\begin{array}{l}\text { Medical Tourism } \\
\text { Index (MTI) }\end{array}$ & $\begin{array}{c}\text { International Tourist } \\
\text { Arrivals }\end{array}$ & $\begin{array}{c}\text { International Tourism } \\
\text { Revenue }\end{array}$ & Investment Growth \\
\hline Above average & $\begin{array}{c}\text { Canada } \\
\text { United Kingdom } \\
\text { Israel } \\
\text { Singapore } \\
\underline{\text { India }} \\
\text { Germany } \\
\text { France } \\
\text { Italy } \\
\text { Colombia } \\
\text { Spain } \\
\text { Japan } \\
\text { Panama } \\
\text { Costa Rica } \\
\text { Dominican Republic } \\
\text { Jamaica } \\
\text { Thailand } \\
\text { Philippines } \\
\text { Argentina } \\
\text { Brazil } \\
\text { China } \\
\text { Poland }\end{array}$ & 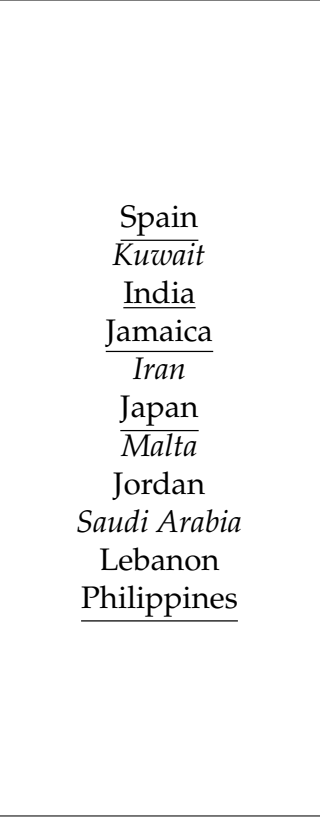 & 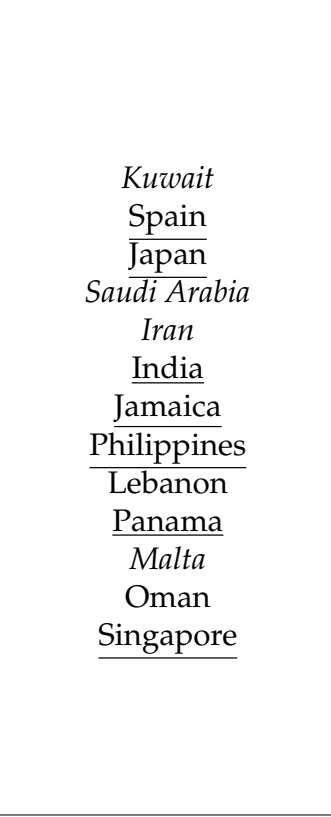 & $\begin{array}{l}\frac{\text { India }}{\text { Panama }} \\
\frac{\text { Spain }}{\text { Philippines }} \\
\text { Japan } \\
\overline{\text { Russia }} \\
\text { Iran } \\
\text { Lebanon } \\
\text { Israel } \\
\text { Singapore } \\
\text { Kuwait } \\
\text { Oman } \\
\text { Jamaica } \\
\text { Malta } \\
\text { Saudi Arabia }\end{array}$ \\
\hline Below average & $\begin{array}{c}\text { Malta } \\
\text { South Africa } \\
\text { Egypt } \\
\text { Mexico } \\
\text { Qatar } \\
\text { Morocco } \\
\text { Turkey } \\
\text { Jordan } \\
\text { Russia } \\
\text { Oman } \\
\text { Tunisia } \\
\text { Kuwait } \\
\text { Saudi Arabia } \\
\text { Bahrain } \\
\text { Lebanon } \\
\text { Iran }\end{array}$ & $\begin{array}{c}\text { Russia } \\
\text { Singapore } \\
\text { Morocco } \\
\text { Panama } \\
\text { Oman } \\
\text { South Africa } \\
\text { United Kingdom } \\
\text { Tunisia } \\
\text { Brazil } \\
\text { Canada } \\
\text { Israel } \\
\text { Qatar } \\
\text { Italy } \\
\text { Bahrain } \\
\text { Colombia } \\
\text { Costa Rica } \\
\text { Argentina } \\
\text { Germany } \\
\text { Turkey } \\
\text { France } \\
\text { Dominican Republic } \\
\text { Egypt } \\
\text { Thailand } \\
\text { Poland } \\
\text { Mexico } \\
\text { China }\end{array}$ & $\begin{array}{c}\text { Russia } \\
\text { Jordan } \\
\text { Turkey } \\
\text { Morocco } \\
\text { Tunisia } \\
\text { South Africa } \\
\text { China } \\
\text { Italy } \\
\text { Israel } \\
\text { Dominican Republic } \\
\text { Qatar } \\
\text { Mexico } \\
\text { Germany } \\
\text { Canada } \\
\text { Argentina } \\
\text { United Kingdom } \\
\text { Costa Rica } \\
\text { France } \\
\text { Colombia } \\
\text { Thailand } \\
\text { Egypt } \\
\text { Bahrain } \\
\text { Poland } \\
\text { Brazil }\end{array}$ & $\begin{array}{c}\text { Canada } \\
\text { Jordan } \\
\text { Tunisia } \\
\text { Colombia } \\
\text { South Africa } \\
\text { Dominican Republic } \\
\text { Costa Rica } \\
\text { Morocco } \\
\text { Germany } \\
\text { Qatar } \\
\text { Turkey } \\
\text { China } \\
\text { Mexico } \\
\text { Bahrain } \\
\text { Argentina } \\
\text { Egypt } \\
\text { Italy } \\
\text { France } \\
\text { Thailand } \\
\text { Brazil } \\
\text { United Kingdom } \\
\text { Poland }\end{array}$ \\
\hline
\end{tabular}

For the underlined countries all the studied indicators are above average (except Singapore). Countries in italics have above-average value of MTI and below-average value of other studied indicators.

Based on the assumption that medical tourism development is associated with the development of national healthcare systems, we studied the links between medical tourism and (1) indicators of health care resources in the studied countries (number of hospital beds and doctors / physicians per 1000 people) and (2) the amount and sources of funding for the healthcare system. We did not reveal any connections in the first direction, and hence, we can state that the internal (domestic) system of public healthcare services and medical tourism are separate directions of medical activity. However, in the second direction, the 
results were somewhat different. Accordingly, countries with relatively high healthcare expenditures (above average) and a predominantly public funding occupied high positions in the medical tourism ranking (Germany, Canada, Japan, France, Great Britain, Israel, Italy, Spain), whereas a high share of private expenditures with minor state and total healthcare funding provided a low ranking of the countries in terms of medical tourism (India, Philippines, Egypt, Morocco, Tunisia and China) (Table 3). At the same time, within the framework of the study, the countries of so-called "ultra-modern development" appeared to be very peculiar. For instance, we could observe Qatar (the MTI ranking was lower than the average, while there were high total and public expenditures on healthcare and a low share of private ones), Singapore (high medical tourism ranking; both public and private expenditures were high), Malta (average medical tourism ranking, high total and public expenditures and low private but high out-of-pocket healthcare expenditures).

Table 2. Results of Correlation Analysis for MTI and International Tourism Indicators.

\begin{tabular}{ccccc}
\hline Indicators & MTI & $\begin{array}{c}\text { International } \\
\text { Tourist Arrivals }\end{array}$ & $\begin{array}{c}\text { Income from } \\
\text { International Tourism }\end{array}$ & $\begin{array}{c}\text { Investment } \\
\text { Growth }\end{array}$ \\
\hline MTI & 1 & & & \\
\hline $\begin{array}{c}\text { International } \\
\text { tourism, arrivals }\end{array}$ & 0.756775 & 1 & 1 \\
\hline $\begin{array}{c}\text { Incoming } \\
\text { International } \\
\text { tourism arrivals }\end{array}$ & 0.777265 & 0.97488 & 0.811382 \\
\hline Investment growth & 0.584937 & 0.858542 & 1 \\
\hline
\end{tabular}

Table 3. Matrix of Grouping Countries by Medical Tourism and Healthcare Funding Indicators.

\begin{tabular}{|c|c|c|c|c|c|}
\hline $\begin{array}{l}\text { The Value of } \\
\text { Indicators }\end{array}$ & $\begin{array}{l}\text { Medical Tourism } \\
\text { Index }\end{array}$ & $\begin{array}{c}\text { Current } \\
\text { Expenditure on } \\
\text { Health per Capita }\end{array}$ & $\begin{array}{l}\text { Domestic General } \\
\text { Government } \\
\text { Expenditure on } \\
\text { Health per Capita }\end{array}$ & $\begin{array}{c}\text { Private Health } \\
\text { Expenditures per } \\
\text { Capita }\end{array}$ & $\begin{array}{c}\text { Out-of-Pocket } \\
\text { Health } \\
\text { Expenditure }\end{array}$ \\
\hline Above average & $\begin{array}{c}\text { Canada } \\
\text { United Kingdom } \\
\text { Israel } \\
\text { Singapore } \\
\text { India } \\
\text { Germany } \\
\text { France } \\
\text { Italy } \\
\text { Colombia } \\
\text { Spain } \\
\text { Japan } \\
\text { Panama } \\
\text { Costa Rica } \\
\text { Dominican } \\
\text { Republic } \\
\text { Jamaica } \\
\text { Thailand } \\
\text { Philippines } \\
\text { Argentina } \\
\text { Brazil } \\
\text { China } \\
\text { Poland }\end{array}$ & $\begin{array}{c}\text { Germany } \\
\text { Canada } \\
\text { France } \\
\text { Japan } \\
\text { United Kingdom } \\
\text { Israel } \\
\text { Italy } \\
\text { Singapore } \\
\text { Spain } \\
\text { Malta } \\
\text { Qatar }\end{array}$ & $\begin{array}{c}\text { Germany } \\
\text { Japan } \\
\text { Canada } \\
\text { France } \\
\text { United Kingdom } \\
\text { Italy } \\
\text { Israel } \\
\text { Spain } \\
\text { Qatar } \\
\text { Malta } \\
\text { Singapore }\end{array}$ & $\begin{array}{c}\text { Bahrain } \\
\text { China } \\
\text { Russia } \\
\text { Tunisia } \\
\text { South Africa } \\
\text { Jordan } \\
\text { Mexico } \\
\text { Iran } \\
\text { Lebanon } \\
\text { Singapore } \\
\text { Dominican } \\
\text { Republic } \\
\text { Brazil } \\
\text { Morocco } \\
\text { Philippines } \\
\text { Egypt } \\
\text { India }\end{array}$ & $\begin{array}{l}\text { Brazil } \\
\text { Panama } \\
\text { Bahrain } \\
\text { Jordan } \\
\text { Singapore } \\
\text { Lebanon } \\
\text { Malta } \\
\text { China } \\
\text { Tunisia } \\
\text { Russia } \\
\text { Mexico } \\
\text { Iran } \\
\text { Dominican } \\
\text { Republic } \\
\text { Philippines } \\
\text { Morocco } \\
\text { Egypt } \\
\text { India }\end{array}$ \\
\hline
\end{tabular}


Table 3. Cont.

\begin{tabular}{|c|c|c|c|c|c|}
\hline $\begin{array}{l}\text { The Value of } \\
\text { Indicators }\end{array}$ & $\begin{array}{l}\text { Medical Tourism } \\
\text { Index }\end{array}$ & $\begin{array}{c}\text { Current } \\
\text { Expenditure on } \\
\text { Health per Capita }\end{array}$ & $\begin{array}{l}\text { Domestic General } \\
\text { Government } \\
\text { Expenditure on } \\
\text { Health per Capita }\end{array}$ & $\begin{array}{c}\text { Private Health } \\
\text { Expenditures per } \\
\text { Capita }\end{array}$ & $\begin{array}{l}\text { Out-of-Pocket } \\
\text { Health } \\
\text { Expenditure }\end{array}$ \\
\hline Below average & $\begin{array}{c}\text { Malta } \\
\text { South Africa } \\
\text { Egypt } \\
\text { Mexico } \\
\text { Qatar } \\
\text { Morocco } \\
\text { Turkey } \\
\text { Jordan } \\
\text { Russia } \\
\text { Oman } \\
\text { Tunisia } \\
\text { Kuwait } \\
\text { Saudi Arabia } \\
\text { Bahrain } \\
\text { Lebanon } \\
\text { Iran }\end{array}$ & $\begin{array}{c}\text { Saudi Arabia } \\
\text { Bahrain } \\
\text { Kuwait } \\
\text { Panama } \\
\text { Argentina } \\
\text { Costa Rica } \\
\text { Poland } \\
\text { Brazil } \\
\text { Lebanon } \\
\text { Oman } \\
\text { Mexico } \\
\text { Russia } \\
\text { Turkey } \\
\text { Iran } \\
\text { South Africa } \\
\text { Colombia } \\
\text { Dominican } \\
\text { Republic } \\
\text { China } \\
\text { Jordan } \\
\text { Jamaica } \\
\text { Tunisia } \\
\text { Thailand } \\
\text { Morocco } \\
\text { Egypt } \\
\text { Philippines } \\
\text { India }\end{array}$ & $\begin{array}{c}\text { Kuwait } \\
\text { Saudi Arabia } \\
\text { Argentina } \\
\text { Panama } \\
\text { Bahrain } \\
\text { Costa Rica } \\
\text { Oman } \\
\text { Poland } \\
\text { Turkey } \\
\text { Brazil } \\
\text { Lebanon } \\
\text { Colombia } \\
\text { Russia } \\
\text { Mexico } \\
\text { China } \\
\text { Iran } \\
\text { South Africa } \\
\text { Dominican } \\
\text { Republic } \\
\text { Jamaica } \\
\text { Thailand } \\
\text { Jordan } \\
\text { Tunisia } \\
\text { Morocco } \\
\text { Egypt } \\
\text { Philippines } \\
\text { India }\end{array}$ & $\begin{array}{c} \\
\text { Oman } \\
\text { Japan } \\
\text { Kuwait } \\
\text { Qatar } \\
\text { United Kingdom } \\
\text { Turkey } \\
\text { Germany } \\
\text { France } \\
\text { Thailand } \\
\text { Italy } \\
\text { Argentina } \\
\text { Canada } \\
\text { Costa Rica } \\
\text { Spain } \\
\text { Poland } \\
\text { Colombia } \\
\text { Saudi Arabia } \\
\text { Panama } \\
\text { Israel } \\
\text { Jamaica } \\
\text { Malta }\end{array}$ & $\begin{array}{c}\text { Oman } \\
\text { South Africa } \\
\text { Qatar } \\
\text { France } \\
\text { Thailand } \\
\text { Japan } \\
\text { Germany } \\
\text { Canada } \\
\text { United Kingdom } \\
\text { Saudi Arabia } \\
\text { Argentina } \\
\text { Kuwait } \\
\text { Colombia } \\
\text { Turkey } \\
\text { Jamaica } \\
\text { Costa Rica } \\
\text { Israel } \\
\text { Italy } \\
\text { Poland } \\
\text { Spain }\end{array}$ \\
\hline
\end{tabular}

Nonetheless, we have found no stable correlation and regression relationships between these indicators, which again confirms the separate positioning and development of the internal healthcare system and exports of healthcare services (at least for the vast majority of the studied countries).

A correlation analysis of IMD and international indices characterizing the institutional environment for the protection of rights and freedoms of both business and citizens revealed a significant relationship between MTI and the Corruption Perceptions Index (CPI, correlation coefficient was $r=0.594)$, Doing Business index $(\mathrm{DB}$, correlation coefficient was $r=0.542$ ), the International Property Right Index (IPRI, correlation coefficient was $r=0.509$ ), Political Rights Index (PRI, correlation coefficient was $r=0.664$ ) and Civil Liberties Index (CLI, correlation coefficient was $r=0.703$ ). The relationship between medical tourism and the Political Rights Index (PRI) and Civil Liberties Index (CLI) was the closest to the normal distribution, and it was also tangible. However, these dependencies cannot be considered causal due to the low value of the coefficient of determination, $R^{2}$. Figure 4 shows the scatter plots without identifying the countries, since the relationships between the indices were statistically insignificant. Thus, the scatter plots illustrate the general characteristics of such relationships. 


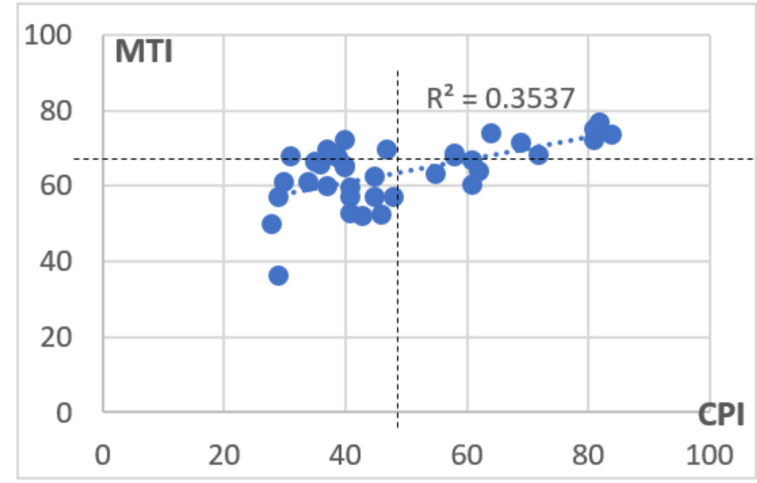

(a) Scattering of Countries by Indicators of MTI and CPI.

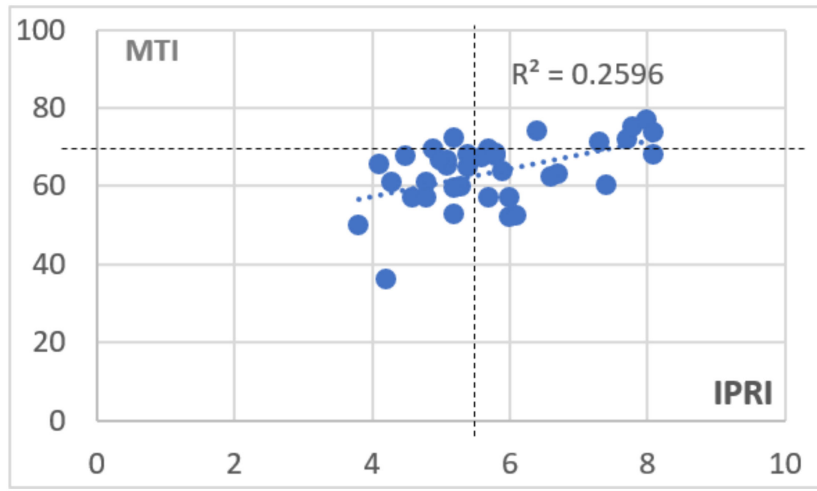

(c) Scattering of Countries by Indicators of MTI and IPRI.

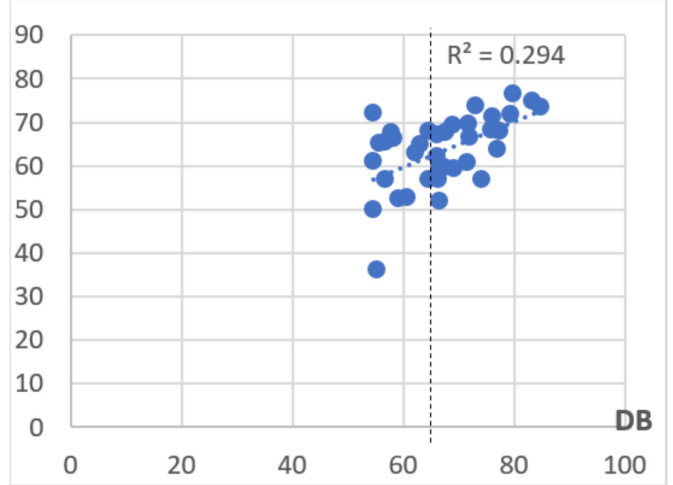

(b) Scattering of Countries by Indicators of MTI and DB.

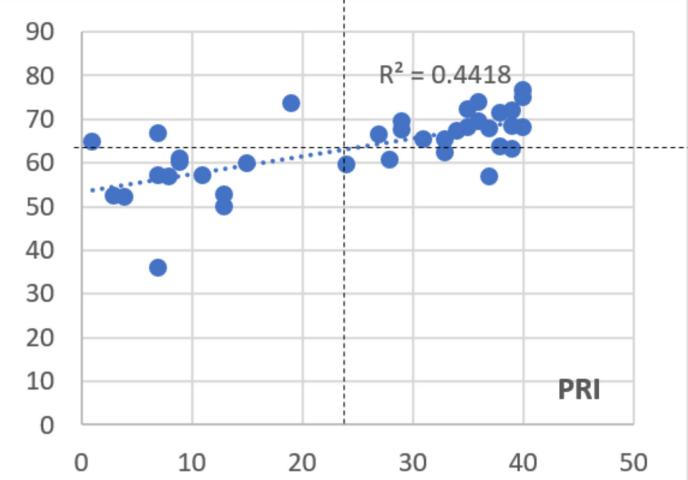

(d) Scattering of Countries by Indicators of MTI and PRI.

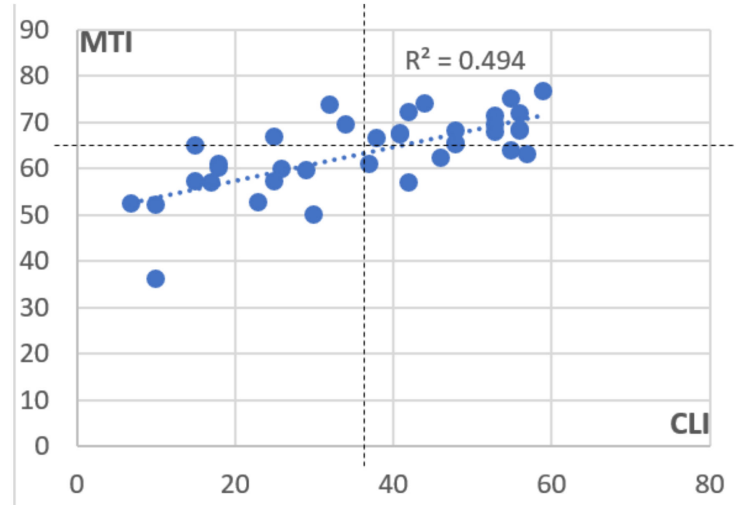

(e) Scattering of Countries by Indicators of MTI and CLI.

Figure 4. Scattering of Countries by Indicators of MTI and (a) international Corruption Perceptions Indices (CPI), (b) Doing Business (DB), (c) the International Property Right Indices (IPRI), (d) Political Rights Indices (PRI) and (e) Civil Liberties Indices (CLI).

The grouping of the countries according to the ranking values of the studied indices revealed the following features: the MTI's top-ranked and bottom-ranked countries occupied similar positions in other rankings. The top countries were the United Kingdom, Germany, Canada and Japan (these countries were in the top 10 for all rankings); the bottom-ranked countries were Iran, Lebanon and Saudi Arabia (except for the International Property Right Index). Israel, Italy, Spain and Poland occupied high ranking positions (above average). At the same time, within the framework of the study, some countries appeared to be very peculiar. Particularly, these included Singapore (high ranking positions in all ratings, except for the Political Rights Index (PRI) and Civil Liberties Index (CLI)); India had the 5th place in the medical tourism ranking and the last ranking in Doing Business index; it also ranked low in Corruption Perceptions Indices (CPI) and had higher than average ranking positions 
in the indices of political rights and civil liberties; Malta had high and medium rankings in all indices except Doing Business; Colombia had a high ranking for MTI (9th place) and Doing Business and ranked below average for all other indicators.

\section{Conclusions}

The conducted research revealed that various factors have an influence upon the formation of medical tourism destinations in different countries. In the cases of countries with high social and economic development (European countries, Canada, Japan), both environment and tourism, including the medical one, develop in a balanced and unidirectional way, which contributes to the formation of resources for further development. The countries of so-called "ultra-modern development" (Asian, Arab and Middle Eastern countries) are different in terms of social and institutional characteristics, as well as regarding sources of funding for the domestic healthcare system; however, they also form a sufficiently powerful and competitive market for medical tourism. Nevertheless, all countries have some features in common as well. Particularly, there is a link between medical tourism and healthcare funding, international tourism and the development of political and civil liberties, but the cause-and-effect (causal) links between them do not exist, or they are not significant enough (as in the case of revenues from international tourism). This fact indicates the presence of other, internal factors and their configurations, which form a positive image of countries for medical tourism development and, hence, substantiates further analysis in this direction in terms of individual countries or destinations.

Each country has its own model of healthcare system functioning, which is the basis for forming export medical services, i.e., the development of medical tourism. However, the structure of financing the national models is similar. In turn, medical tourism development is caused not only by the healthcare system evolving, but by infrastructural and institutional factors formed under the influence of national socio-economic policy and government cooperation with businesses and households under financing activities.

In order to have a successful medical tourism industry, it is necessary to create conditions for tourists that would meet or even exceed their expectations, while creating more benefits for locals than costs [38]. This should be linked to the country's macroeconomic policy through properly chosen fiscal and monetary policies, as well as proper regulation of the labor market [39] and foreign economic performance of the state.

It is also worth noting that the COVID-19 pandemic challenges have significantly affected both the functioning of national healthcare systems and the development of medical tourism [40]. Therefore, it seems relevant and promising to further investigate the established characteristics in the years of the Medical Tourism Index formation and find common features in the context of countries and their associations, as well as to develop scenarios for the further development of medical tourism.

Author Contributions: Conceptualization, V.V., L.B. and O.P.; methodology, V.V., L.B. and O.P.; software, O.P.; validation, V.V., L.B. and O.P.; formal analysis, O.P.; investigation, V.V., L.B. and O.P.; resources, V.V. and O.P.; data curation, V.V. and O.P.; writing—original draft preparation, V.V., L.B. and O.P.; writing — review and editing, V.V., L.B. and O.P.; visualization, V.V. and O.P.; supervision, L.B.; project administration, V.V. and L.B. All authors have read and agreed to the published version of the manuscript.

Funding: This research received no external funding.

Data Availability Statement: The data used in this study are publicly available on the following websites: https:/ / www.unwto.org/global-and-regional-tourism-performance (accessed on 28 July 2012); https:/ / www.medicaltourism.com/destination-healthcare-guide (accessed on 28 July 2012); https:/ / www.weforum.org/reports/the-travel-tourism-competitiveness-report-2017 (accessed on 28 July 2012); https:/ / knoema.com/atlas (accessed on 28 July 2012); http:/ /www3.weforum.org/docs/ GCR2016-2017/05FullReport/TheGlobalCompetitivenessReport2016-2017_FINAL.pdf (accessed on 28 July 2012); http:/ /hdr.undp.org/en/content/human-development-report-2016 (accessed on 28 July 2012); https:/ /images.transparencycdn.org/images/2016_CPIReport_EN.pdf (accessed on 28 July 2021). 
Conflicts of Interest: The authors declare no conflict of interest.

\section{Appendix A}

Table A1. Baseline Data for Assessing Economic Development and International Tourism Development.

\begin{tabular}{|c|c|c|c|c|c|c|}
\hline Country & $\begin{array}{l}\text { Arbitrary } \\
\text { Symbol }\end{array}$ & $\begin{array}{c}\text { Travel and } \\
\text { Tourism } \\
\text { Competitiveness } \\
\text { Index }\end{array}$ & $\begin{array}{c}\text { International } \\
\text { Tourism, } \\
\text { Arrivals, } \\
1000 \text { People }\end{array}$ & $\begin{array}{l}\text { International } \\
\text { Tourism } \\
\text { Incoming, } \\
\text { mln.USD }\end{array}$ & $\begin{array}{l}\text { Investment } \\
\text { Growth, \% }\end{array}$ & $\begin{array}{c}\text { GDP per } \\
\text { Capita }\end{array}$ \\
\hline Argentina & Ar & 4.05 & 6668 & 5466 & 6 & $20,307.9$ \\
\hline Bahrain & Bahr & 2.89 & 10,158 & 4021 & 0.3 & $44,790.1$ \\
\hline Brazil & Braz & 4.49 & 6547 & 6613 & 17.3 & $14,256.2$ \\
\hline Canada & $\mathrm{Ca}$ & 4.97 & 17,971 & 18,144 & 16.1 & $46,480.47$ \\
\hline China & $\mathrm{Ch}$ & 4.72 & 59,270 & 44,432 & 134.6 & $13,572.62$ \\
\hline Colombia & Col & 3.83 & 3254 & 5584 & 2.4 & $13,952.14$ \\
\hline Costa Rica & CR & 4.22 & 2925 & 3776 & 0.4 & $18,008.6$ \\
\hline $\begin{array}{c}\text { Dominican } \\
\text { Republic }\end{array}$ & DR & 3.62 & 5959 & 6720 & 0.6 & $16,109.86$ \\
\hline Egypt & $\mathrm{Eg}$ & 3.64 & 5258 & 3306 & 4.5 & $11,192.37$ \\
\hline France & $\mathrm{Fr}$ & 5.32 & 82,682 & 63,557 & 37.6 & $42,920.27$ \\
\hline Germany & $\mathrm{Ge}$ & 5.28 & 35,555 & 52,229 & 24.5 & $50,564.25$ \\
\hline India & In & 4.18 & 14,570 & 23,111 & 37.9 & 5839.9 \\
\hline Iran & Ir & 3.43 & 4942 & 3914 & 2.8 & $14,011.55$ \\
\hline Israel & Isr & 3.84 & 2900 & 6587 & 3 & $37,843.98$ \\
\hline Italy & It & 4.99 & 52,372 & 42,423 & 9.9 & $39,922.91$ \\
\hline Jamaica & Jam & 3.71 & 2182 & 2539 & 0.4 & 9193.3 \\
\hline Japan & $\mathrm{Ja}$ & 5.26 & 24,040 & 27,285 & 36 & $39,970.68$ \\
\hline Jordan & Jor & 3.63 & 3567 & 4943 & 0.7 & 9283.871 \\
\hline Kuwait & Kuw & 3.33 & 7055 & 831 & 0.4 & $44,985.35$ \\
\hline Lebanon & Leb & 3.37 & 1688 & 7373 & 1.2 & $15,487.11$ \\
\hline Malta & Mal & 4.25 & 1966 & 1451 & 0.3 & $39,699.61$ \\
\hline Mexico & Mex & 4.54 & & 20,619 & 8.4 & $19,314.26$ \\
\hline Morocco & Mor & 3.81 & 10,332 & 7481 & 4.4 & 7112.99 \\
\hline Oman & $\mathrm{Om}$ & 3.78 & 2335 & 2390 & 0.7 & $28,926.14$ \\
\hline Panama & $\mathrm{Pa}$ & 4.37 & 1921 & 6280 & 1.2 & $27,828.52$ \\
\hline Philippines & $\mathrm{Ph}$ & 3.6 & 5967 & 6289 & 1.8 & 7703.75 \\
\hline Poland & Pol & 4.11 & 17,471 & 12,052 & 2.6 & $28,283.7$ \\
\hline Qatar & $\mathrm{Qa}$ & 4.08 & 2938 & 12,593 & 1.5 & $83,102.49$ \\
\hline Russia & $\widehat{\mathrm{Ru}}$ & 4.15 & 33,729 & 12,822 & 5.4 & $24,125.4$ \\
\hline Saudi Arabia & Sar & 3.82 & 18,044 & 13,438 & 23.8 & $45,485.66$ \\
\hline Singapore & $\operatorname{Sin}$ & 4.85 & 12,913 & 18,944 & 15.2 & $89,386.08$ \\
\hline South Africa & Saf & 4.01 & 10,044 & 8807 & 4.8 & $12,592.49$ \\
\hline Spain & $\mathrm{Sp}$ & 5.43 & 75,315 & 66,982 & 15.9 & $37,282.44$ \\
\hline Thailand & Th & 4.38 & 32,530 & 48,459 & 7.1 & $16,618.76$ \\
\hline Tunisia & Tun & 3.5 & 5724 & 1706 & 0.8 & $10,359.3$ \\
\hline Turkey & Tur & 4.14 & 30,289 & 26,788 & 21.4 & $26,329.36$ \\
\hline United Kingdom & UK & 5.2 & 35,814 & 47,777 & 23.6 & $44,162.55$ \\
\hline
\end{tabular}


Table A2. Baseline Data for Assessing the Development of National Healthcare Systems.

\begin{tabular}{|c|c|c|c|c|c|c|c|}
\hline Country & $\begin{array}{c}\text { Arbitrary } \\
\text { Symbol }\end{array}$ & $\begin{array}{c}\text { Current } \\
\text { Expenditure } \\
\text { on Health } \\
\text { per Capita, } \\
\text { US dollars }\end{array}$ & $\begin{array}{l}\text { Domestic } \\
\text { General } \\
\text { Government } \\
\text { Expenditure on } \\
\text { Health per Capita, } \\
\text { US Dollars }\end{array}$ & $\begin{array}{c}\text { Private } \\
\text { Health } \\
\text { Expenditures } \\
\text { per Capita, } \\
\text { US Dollars }\end{array}$ & $\begin{array}{c}\text { Out-of- } \\
\text { Pocket } \\
\text { Expenditure, } \\
\text { Current } \\
\text { Expend.\% }\end{array}$ & $\begin{array}{c}\text { Doctors } \\
\text { per } 1000 \\
\text { People }\end{array}$ & $\begin{array}{c}\text { Hospital } \\
\text { Beds per } \\
1000 \\
\text { Population }\end{array}$ \\
\hline Argentina & $\mathrm{Ar}$ & 959 & 711 & 1311 & 15.98 & 4 & 4.95 \\
\hline Bahrain & Bahr & 1099 & 675 & 1179 & 27.99 & 0.9 & 1.89 \\
\hline Brazil & Braz & 769 & 342 & 1077 & 27.41 & 2.2 & 2.11 \\
\hline Canada & $\mathrm{Ca}$ & 4518 & 3339 & 1041 & 14.13 & 2.3 & 2.6 \\
\hline China & $\mathrm{Ch}$ & 398 & 231 & 985 & 35.91 & 1.9 & 2.12 \\
\hline Colombia & Col & 419 & 288 & 864 & 16.37 & 2 & 1.68 \\
\hline Costa Rica & CR & 887 & 650 & 785 & 22.21 & 1.4 & 1.15 \\
\hline $\begin{array}{c}\text { Dominican } \\
\text { Republic }\end{array}$ & DR & 414 & 189 & 694 & 44.62 & 1.6 & 1.44 \\
\hline Egypt & $\mathrm{Eg}$ & 151 & 47 & 691 & 59.01 & 0.8 & 1.43 \\
\hline France & $\mathrm{Fr}$ & 4257 & 3272 & 667 & 9.55 & 3.2 & 6.06 \\
\hline Germany & $\mathrm{Ge}$ & 4734 & 3657 & 427 & 12.88 & 4.2 & 8.06 \\
\hline India & In & 61 & 16 & 424 & 63.21 & 0.8 & 0.48 \\
\hline Iran & Ir & 454 & 230 & 388 & 42.29 & 1.1 & 1.7 \\
\hline Israel & Isr & 2856 & 1815 & 358 & 22.33 & 3.5 & 2.99 \\
\hline Italy & It & 2736 & 2042 & 335 & 22.93 & 4 & 3.17 \\
\hline Jamaica & Jam & 280 & 179 & 309 & 17.95 & 0.5 & 1.78 \\
\hline Japan & $\mathrm{Ja}$ & 4175 & 3508 & 253 & 12.83 & 2.4 & 13.11 \\
\hline Jordan & Jor & 297 & 147 & 248 & 30.1 & 1.4 & 1.4 \\
\hline Kuwait & Kuw & 1073 & 901 & 237 & 16.04 & 2.6 & 2.04 \\
\hline Lebanon & Leb & 667 & 332 & 226 & 33.53 & 2 & 2.73 \\
\hline Malta & Mal & 2328 & 1464 & 225 & 35.02 & 2.9 & 4.67 \\
\hline Mexico & Mex & 475 & 249 & 224 & 40.52 & 2.3 & 1 \\
\hline Morocco & Mor & 153 & 65 & 202 & 54.32 & 0.7 & 1.1 \\
\hline Oman & $\mathrm{Om}$ & 645 & 573 & 198 & 6.12 & 1.9 & 1.49 \\
\hline Panama & $\mathrm{Pa}$ & 1040 & 682 & 172 & 27.43 & 1.6 & 2.23 \\
\hline Philippines & $\mathrm{Ph}$ & 130 & 41 & 167 & 53.69 & 0.6 & 0.3 \\
\hline Poland & Pol & 813 & 560 & 150 & 23.08 & 2.4 & 6.64 \\
\hline Qatar & $\mathrm{Qa}$ & 1800 & 1491 & 131 & 7.95 & 2.7 & 1.2 \\
\hline Russia & $\widehat{\mathrm{Ru}}$ & 469 & 267 & 112 & 40.48 & 4 & 8.16 \\
\hline Saudi Arabia & Sar & 1166 & 778 & 104 & 15.71 & 2.4 & 2.23 \\
\hline Singapore & Sin & 2490 & 1179 & 101 & 32.66 & 2.3 & 2.48 \\
\hline South Africa & Saf & 428 & 230 & 101 & 7.75 & 0.8 & 0.3 \\
\hline Spain & $\mathrm{Sp}$ & 2391 & 1700 & 89 & 23.94 & 3.8 & 2.97 \\
\hline Thailand & Th & 225 & 171 & 88 & 11.35 & 0.4 & 0.3 \\
\hline Tunisia & Tun & 257 & 145 & 72 & 39.9 & 1.3 & 2.18 \\
\hline Turkey & Tur & 469 & 368 & 54 & 16.47 & 1.8 & 2.75 \\
\hline United Kingdom & UK & 3945 & 3160 & 45 & 15.49 & 2.8 & 2.57 \\
\hline
\end{tabular}

Table A3. Baseline Data for Assessing Institutional Environment.

\begin{tabular}{cccccccccc}
\hline Country & MTI & GCI & HDI & CPI & DB & IPRI & IEF & PRI & CLI \\
\hline Argentina & 65.37 & 3.81 & 0.827 & 36 & 56.73 & 4.1 & 43.8 & 31 & 48 \\
Bahrain & 51.99 & 4.47 & 0.824 & 43 & 66.64 & 6 & 74.3 & 4 & 10 \\
Brazil & 65.22 & 4.06 & 0.754 & 40 & 55.62 & 5.1 & 56.5 & 33 & 48 \\
Canada & 76.62 & 5.27 & 0.92 & 82 & 79.76 & 8 & 78 & 40 & 59 \\
China & 64.78 & 4.95 & 0.738 & 40 & 63.12 & 5.4 & 52 & 1 & 15 \\
Colombia & 69.48 & 4.3 & 0.727 & 37 & 68.86 & 4.9 & 70.8 & 29 & 34 \\
Costa Rica & 67.67 & 4.41 & 0.776 & 58 & 67.67 & 5.8 & 67.4 & 37 & 53 \\
Dominican & 67.58 & 3.94 & 0.722 & 31 & 57.9 & 4.5 & 61 & 29 & 41 \\
Republic & & & & & & & & &
\end{tabular}


Table A3. Cont.

\begin{tabular}{cccccccccc}
\hline Country & MTI & GCI & HDI & CPI & DB & IPRI & IEF & PRI & CLI \\
\hline Egypt & 60.92 & 3.67 & 0.691 & 34 & 54.7 & 4.3 & 56 & 9 & 18 \\
France & 71.22 & 5.2 & 0.897 & 69 & 76.15 & 7.3 & 62.3 & 38 & 53 \\
Germany & 71.9 & 5.57 & 0.926 & 81 & 79.5 & 7.7 & 74.4 & 39 & 56 \\
India & 72.1 & 4.52 & 0.624 & 40 & 54.52 & 5.2 & 56.2 & 35 & 42 \\
Iran & 36 & 4.12 & 0.774 & 29 & 55.38 & 4.2 & 43.5 & 7 & 10 \\
Israel & 73.91 & 5.18 & 0.899 & 64 & 73 & 6.4 & 70.7 & 36 & 44 \\
Italy & 69.5 & 4.5 & 0.887 & 47 & 71.69 & 5.7 & 61.2 & 36 & 53 \\
Jamaica & 67.17 & 4.13 & 0.73 & 39 & 66.19 & 5.6 & 67.4 & 34 & 41 \\
Japan & 68 & 5.48 & 0.903 & 72 & 77.53 & 8.1 & 73.1 & 40 & 56 \\
Jordan & 57.02 & 4.28 & 0.741 & 48 & 56.74 & 5.7 & 68.3 & 11 & 25 \\
Kuwait & 52.69 & 4.53 & 0.8 & 41 & 60.66 & 5.2 & 62.7 & 13 & 23 \\
Lebanon & 49.92 & 3.84 & 0.763 & 28 & 54.71 & 3.8 & 59.5 & 13 & 30 \\
Malta & 62.97 & 4.52 & 0.856 & 55 & 62.28 & 6.7 & 66.7 & 39 & 57 \\
Mexico & 60.7 & 4.41 & 0.762 & 30 & 71.64 & 4.8 & 65.2 & 28 & 37 \\
Morocco & 59.77 & 4.2 & 0.647 & 37 & 67.4 & 5.3 & 61.3 & 15 & 26 \\
Oman & 56.9 & 4.28 & 0.796 & 45 & 66.34 & 6 & 67.1 & 8 & 17 \\
Panama & 67.93 & 4.51 & 0.788 & 38 & 64.73 & 5.4 & 64.8 & 35 & 48 \\
Philippines & 66.4 & 4.36 & 0.682 & 35 & 58.23 & 5.1 & 63.1 & 27 & 38 \\
Poland & 63.79 & 4.56 & 0.855 & 62 & 76.93 & 5.9 & 69.3 & 38 & 55 \\
Qatar & 60.07 & 5.23 & 0.856 & 61 & 66.49 & 7.4 & 70.7 & 9 & 18 \\
Russia & 57.01 & 4.51 & 0.804 & 29 & 74.1 & 4.6 & 50.6 & 7 & 15 \\
Saudi Arabia & 52.43 & 4.84 & 0.847 & 46 & 59.16 & 6.1 & 62.1 & 3 & 7 \\
Singapore & 73.56 & 5.72 & 0.925 & 84 & 84.89 & 8.1 & 87.8 & 19 & 32 \\
South Africa & 62.2 & 4.47 & 0.666 & 45 & 66.24 & 6.6 & 61.9 & 33 & 46 \\
Spain & 68.29 & 4.68 & 0.884 & 58 & 75.93 & 5.8 & 68.5 & 39 & 56 \\
Thailand & 66.6 & 4.64 & 0.74 & 61 & 71.94 & 5 & 63.9 & 7 & 25 \\
Tunisia & 56.78 & 3.92 & 0.725 & 41 & 64.57 & 4.8 & 57.6 & 37 & 42 \\
Turkey & 59.49 & 4.39 & 0.767 & 41 & 69.14 & 5.2 & 62.1 & 24 & 29 \\
United Kingdom & 74.87 & 5.49 & 0.909 & 81 & 83.34 & 7.8 & 76.4 & 40 & 55
\end{tabular}

Legend: MTI-Medical Tourism Index; GCI—Global Competitiveness Index; HDI—Human Development Index; CPI—Corruption Perceptions Index; DB-Doing Business; IPRI—International Property Right Index; IEF-Index of Economic Freedom; PRI—Political Rights Index; CLI—Civil Liberties Index.

Table A4. Stepwise Regression Analysis of the Impact of Changes in International Tourism Indicators $\left(\mathrm{x}_{1}-\mathrm{x}_{3}\right)$ on the Ranking Value of the Medical Tourism Index MTI (y).

\begin{tabular}{|c|c|c|c|c|c|c|}
\hline \multirow{2}{*}{$\begin{array}{l}\text { Resulting } \\
\text { Indicator (y) }\end{array}$} & \multirow[b]{2}{*}{ Impact Factors (x) } & \multirow[b]{2}{*}{ Equation } & \multicolumn{4}{|c|}{ Parameters } \\
\hline & & & $\begin{array}{l}\text { Correlation } \\
\text { Coefficient, } \mathrm{R}\end{array}$ & $\begin{array}{c}\text { Coefficient of } \\
\text { Determination, } R^{2}\end{array}$ & $\begin{array}{c}\text { F Fact, } \\
(p=0.95)\end{array}$ & $\begin{array}{l}\mid t \text {-Fact } \mid \\
(p=0.95)\end{array}$ \\
\hline MTI & $\begin{array}{c}\mathrm{x}_{1}- \\
\text { International } \\
\text { tourism, arrivals } \\
\mathrm{x}_{2}- \\
\text { Incoming } \\
\text { international } \\
\text { tourism arrivals } \\
\mathrm{x}_{3}- \\
\text { Investment growth }\end{array}$ & $\begin{array}{c}x=57.21+8.83 \\
\times 10^{-5} x_{1}+ \\
+0.00031 x_{2}- \\
0.06 x_{3}\end{array}$ & 0.7823 & 0.6120 & $\begin{array}{c}F \text { crit }=2.8588 \\
17.3547\end{array}$ & $\begin{array}{c}t \text {-crit }=2.03 \\
x_{1}=0.39 \\
x_{2}=1.41 \\
x_{3}=0.82\end{array}$ \\
\hline \multicolumn{7}{|c|}{ Disapplication of factor $x_{1}$} \\
\hline MTI & $\begin{array}{c}\mathrm{x}_{2}- \\
\text { Incoming } \\
\text { international } \\
\text { tourism arrivals } \\
\mathrm{x}_{3}- \\
\text { Investment growth }\end{array}$ & $\begin{array}{l}x=57.33+ \\
0.00039 x_{2} \\
-0.0473 x_{3}\end{array}$ & 0.7812 & 0.6103 & $\begin{array}{c}F \text { crit }=3.2519 \\
F \text { fact }= \\
26.5187\end{array}$ & $\begin{array}{c}t \text {-crit }=2.0301 \\
x_{2}=4.8362 \\
x_{3}=0.7306\end{array}$ \\
\hline
\end{tabular}




\section{References}

1. Simpson, L. The History, Evolution and Future of Medical Tourism. Traveling to Achieve Wellness Is as Old as the Civilization Itself. 2017. Available online: https://www.cobizmag.com/the-history-evolution-and-future-of-medical-tourism (accessed on 1 October 2021).

2. Lubowiecki-Vikuk, A.P. Turystyka medyczna przejawem współczesnych trendów i tendencji w turystyce. Zesz. Nauk. Uniw. Szczecińskiego 2012, 84, 553-568.

3. Woźniak-Holecka, J.; Romaniuk, P.; Holecki, T.; Frączkiewicz-Wronka, A.; Jaruga, S. Health Promotion Development in the Spa Treatment. Perspectives for the European Countries Learned from Poland's Experiences. Front. Pharmacol. 2017, 8, 29. [CrossRef]

4. Carrera, P.M.; Bridges, J.F. Globalization and healthcare: Understanding health and medical tourism. Expert Rev Pharm. Outcomes Res 2006, 6, 447-454. [CrossRef] [PubMed]

5. Connell, J. Medical tourism: Sea, sun, sand and surgery. Tour. Manag. 2006, 27, 1093-1100. [CrossRef]

6. UNWTO. Global and Regional Tourism Performance. Available online: https://www.unwto.org/global-and-regional-tourismperformance (accessed on 3 November 2020).

7. Pennings, G. Reproductive tourism as moral pluralism in motion. J. Med. Ethics 2002, 28, 337-341. [CrossRef] [PubMed]

8. Kmietowicz, Z. GPs to check on patients' residency status to stop "health tourism". BMJ Br. Med. J. 2004, 328, 1217. [CrossRef]

9. Borman, E. Health Tourism: Where Healthcare, Ethics, and the State Collide. BMJ Br. Med. J. 2004, 328, 60-61. [CrossRef]

10. Czyzewski, B.; Polcyn, J.; Hnatyszyn-Dzikowska, A. Concept for Measuring the Efficiency of Public Goods Provision Based on the Education Sector in Poland 1. Ekon. Cas. 2016, 64, 973.

11. Mathijsen, A. Home, sweet home? Understanding diasporic medical tourism behaviour. Exploratory research of Polish immigrants in Belgium. Tour. Manag. 2019, 72, 373-385. [CrossRef]

12. Bergmark, R.; Barr, D.; Garcia, R. Mexican immigrants in the US living far from the border may return to Mexico for health services. J. Immigr. Minor. Health 2010, 12, 610-614. [CrossRef]

13. Connell, J. Medical Tourism; CAB International: Oxfordshire, UK, 2011; 209p.

14. Connell, J. Reducing the scale? From global images to border crossings in medical tourism. Glob. Netw. 2016, 16, 531-550. [CrossRef]

15. Priya, K. Medical Tourism in India: Strengths and Weaknesses. Int. J. Tech. Res. Sci. 2019, 4, 27-30. [CrossRef]

16. Ivars-Baidal, J.; Rodriguez-Sanchez, I.; Vera-Rebollo, J.F. The evolution of mass tourism destinations: New approaches beyond deterministic models in Benidorm (Spain). Tour. Manag. 2013, 34, 184-195. [CrossRef]

17. Pourkhaghan, Z.; Ebrahimi Pour Faez, S.; Pourkhaghan, S.; Ghahrieh, S. Interaction of economic indicators and medical tourism industry. Int. J. Travel Med. Glob. Health 2013, 1, 133-139.

18. Dluhopolskyi, O.; Zatonatska, T.; Lvova, I.; Klapkiv, Y. Regulations for returning labour migrants to Ukraine: International background and national limitations. Comp. Econ. Res. 2019, 22, 45-64. [CrossRef]

19. Galley, G.; Clifton, J. The motivational and demographic characteristics of research ecotourists: Operation Wallacea volunteers in southeast Sulawesi Indonesia. J. Ecotour. 2004, 3, 69-82. [CrossRef]

20. Klapkiv, Y.; Vovk, V.; Klapkiv, L. Comparative Analysis of the Health Care Institutions' Competitiveness Level. Montenegrin J. Econ. 2020, 16, 69-82. [CrossRef]

21. Abubakar, A.M.; Ilkan, M. Impact of online WOM on destination trust and intention to travel: A medical tourism perspective. J. Destin. Mark. Manag. 2016, 5, 192-201. [CrossRef]

22. Beladi, H.; Chao, C.C.; Ee, M.S.; Hollas, D. Medical tourism and health worker migration in developing countries. Econ. Model. 2015, 46, 391-396. [CrossRef]

23. Beladi, H.; Chao, C.C.; Ee, M.S.; Hollas, D. Does medical tourism promote economic growth? A cross-country analysis. J. Travel Res. 2019, 58, 121-135. [CrossRef]

24. Pocock, N.S.; Phua, K.H. Medical tourism and policy implications for health systems: A conceptual framework from a comparative study of Thailand, Singapore and Malaysia. Glob. Health 2011, 7, 12. [CrossRef] [PubMed]

25. Leng, C.H. Medical tourism and the state in Malaysia and Singapore. Glob. Soc. Policy 2010, 10, 336-357. [CrossRef]

26. Belloumi, M. The relationship between tourism receipts, real effective exchange rate and economic growth in Tunisia. Int. J. Tour. Res. 2010, 12, 550-560. [CrossRef]

27. Kaigorodova, G.; Alyakina, D.; Pyrkova, G.; Mustafina, A.; Trynchuk, V. Investment activity of insurers and the state economic growth. Montenegrin J. Econ. 2018, 14, 109-123. [CrossRef]

28. Goh, C.; Law, R. The methodological progress of tourism demand forecasting: A review of related literature. J. Travel Tour. Mark. 2011, 28, 296-317. [CrossRef]

29. Jakovljevic, M.; Potapchik, E.; Popovich, L.; Barik, D.; Getzen, T.E. Evolving health expenditure landscape of the BRICS nations and projections to 2025. Health Econ. 2017, 26, 844-852. [CrossRef]

30. Jakovljevic, M.; Arsenijevic, J.; Pavlova, M.; Verhaeghe, N.; Laaser, U.; Groot, W. Within the triangle of healthcare legacies: Comparing the performance of South-Eastern European health systems. J. Med. Econ. 2017, 20, 483-492. [CrossRef] [PubMed]

31. Medical Tourism Association. The Medical Tourism Index: Methodology. Available online: https://www.medicaltourism.com/ $\mathrm{mti}$ / methodology (accessed on 19 March 2021). 
32. Medical Tourism Association. Destination Healthcare Guide. Available online: https://www.medicaltourism.com/destinationhealthcare-guide (accessed on 3 January 2021).

33. World Economic Forum. The Travel \& Tourism Competitiveness Report. 2017. Available online: https://www.weforum.org/ reports/the-travel-tourism-competitiveness-report-2017 (accessed on 3 April 2021).

34. Knoema. Data Bulletin. Available online: https://knoema.com/atlas (accessed on 8 December 2020).

35. World Economic Forum. The Global Competitiveness Report 2016-2017. Available online: http://www3.weforum.org/docs/ GCR2016-2017/05FullReport/TheGlobalCompetitivenessReport2016-2017_FINAL.pdf (accessed on 3 April 2021).

36. UNDP. Human Development Report 2016: Human Development for Everyone. New York. Available online: http:/ hdr.undp. org/en/content/human-development-report-2016 (accessed on 2 February 2020).

37. Transparency International. Corruption Perceptions Index 2016. Available online: https://images.transparencycdn.org/images/ 2016_CPIReport_EN.pdf (accessed on 2 February 2020).

38. Eslami, S.; Khalifah, Z.; Mardani, A.; Streimikiene, D. Impact of Non-economic Factors on Residents' Support for Sustainable Tourism Development in Langkawi Island, Malaysia. Econ. Sociol. 2018, 11, 181-197. [CrossRef]

39. Klapkiv, Y.M. Strategy of institutional development in the market of insurance. Sci. Bull. Polissia 2016, 4, 132-136.

40. Krstic, K.; Westerman, R.; Chattu, V.K.; Ekkert, N.V.; Jakovljevic, M. Corona-Triggered Global Macroeconomic Crisis of the Early 2020s. Int. J. Environ. Res. Public Health 2020, 17, 9404. [CrossRef] 